\title{
The beginnings, from Lipperhey to Huygens and Cassini
}

\author{
Albert Van Helden
}

Received: 9 January 2009 / Accepted: 4 March 2009 / Published online: 8 April 2009

(C) The Author(s) 2009. This article is published with open access at Springerlink.com

\begin{abstract}
The first century of telescopic astronomy can be divided into two periods. During the first, from 1609 to ca. 1640, observations were made with a simple "Dutch" or "Galilean" telescope with a concave eyepiece. Galileo made all his discoveries with this instrument. Its limited field of view, however, made magnifications of more than about 20 impractical, and therefore this instrument's limit had been reached within a few years. During the second period, ca. 1640-ca. 1700, the simple astronomical telescope came into use, almost immediately augmented with a field lens and an erector lens (the latter used only for terrestrial purposes). Magnifications were increased by increasing the focal lengths of objectives, and this quickly led to very long telescopes, often used without a tube. The astronomical discoveries made possible by this form of the instrument were, however, made with instruments of relatively modest lengths. By the end of the century, very long telescopes fell out of use, while shorter ones were adapted for measurements. Further discoveries became possible only with the reflecting telescope in the second half of the eighteenth century.
\end{abstract}

Keywords Telescope $\cdot$ Galileo $\cdot$ Lipperhey $\cdot$ Huygens $\cdot$ Cassini

\section{The invention of the telescope}

Over the four centuries that separate us from the events in The Hague, in October 1608, a number of men have been proposed as the inventor of the telescope: Hans Lipperhey, Sacharias Janssen, Jacob Metius in the Netherlands,

\footnotetext{
A. Van Helden $(\bowtie)$

University of Utrecht, Utrecht, the Netherlands

e-mail: a.vanhelden@uu.nl
} 

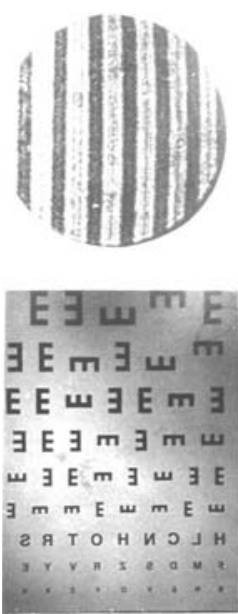
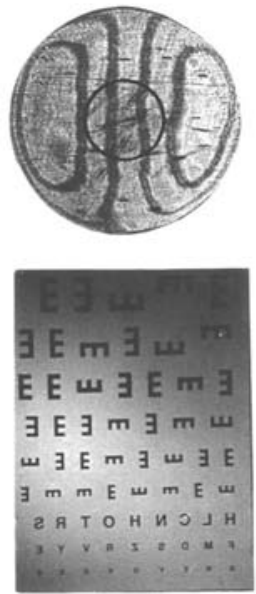
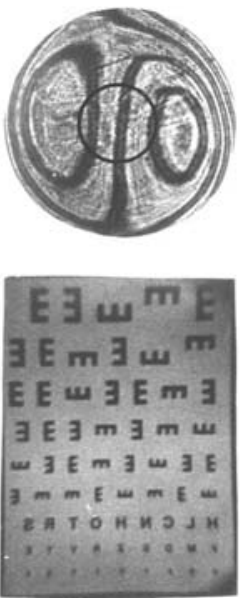
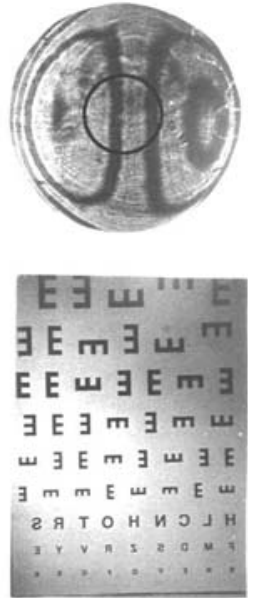

Fig. 1 Ronchi interference tests of sixteenth-century convex spectacle lenses. When the aperture is restricted as shown $(\mathrm{ca} .1 \mathrm{~cm}$ ) these lenses are good enough to produce a reasonably sharp, enlarged image (bottom row). Courtesy Rolf Willach

Raffaelo Gualterotti and Giambaptista della Porta in Italy, an unidentified spectacle maker in the Barcelona region, yes, even Galileo himself. ${ }^{1}$ Lately, some clarity has come to this confusion.

The story has to begin with spectacle lenses. Devices that magnified, made out of quartz or glass, were present in Europe in the first millennium. Spectacles as we know them came into use around the turn of the thirteenth century. These were produced by cutting round discs out of a blown glass ball before it cooled; the discs were then ground and polished on one side. Although these lenses were adequate for use as spectacles-the focused gaze, after all, used only an area of at most $1 \mathrm{~cm}^{2}$ of the lens-they were useless for telescopic purposes. Not until the sixteenth century did some lens-makers begin to work both surfaces. This procedure improved the optical quality immeasurably, so much so that modern tests actually produce recognizable interference patterns, see Fig. $1 .^{2}$

It has recently been shown that learned-and not so learned-men in Europe were searching actively for a telescopic device that would magnify objects many times. Especially in Italy, a group of men examined the optics of mirrors and clearly understood that it required a combination of optical devices. Quite naturally, they looked toward mirrors as the primary receptor,

\footnotetext{
${ }^{1}$ On Lipperhey, Janssen, and Metius, see below; on Gualterotti see [1]. When Porta saw his first spyglass he called it a hoax and that it was taken from one of his works; see Porta to Federico Cesi, 26 August 1610, Le Opere di Galileo Galilei, Edizione Nazionale, X (1968), p. 252. On the Spanish claim, see [2].

${ }^{2}$ For a complete account, see Rolf Willach, The Long Route to the Invention of the Telescope, American Philosophical Society, Transactions, 98, part 5, 2008.
} 
not knowing that mirror surfaces had to be shaped much more precisely than lens surfaces to be useful for this purpose. ${ }^{3}$ But at least it was possible to make large concave mirrors. Lenses could be made only in small sizes, $3-5 \mathrm{~cm}$.

The example of the so-called Elizabethan telescope is illustrative of the situation. It concerned a combination of a large convex lens, a foot in diameter, as the primary receptor, and a small concave mirror as the eyepiece- the opposite of what Italians were thinking of. But here, too, it was impossible to make a $30 \mathrm{~cm}$ convex lens with reasonable optical properties when William Bourne penned his little treatise ca. 1580. ${ }^{4}$ It is somewhat reminiscent of the large optical mirrors pursued in Italy, partly real and partly mythical. Moreover, the small concave mirror in this combination, presumably a few centimeter in diameter, was just as impossible to figure sufficiently accurately. Yet, like the Italian pursuit of large mirrors, it testifies to the fact that theory was not the problem: these men knew perfectly well that a device that produced sharply defined enlarged images had to consist of a combination of (at least) two optical components, where the primary receptor could be either a convex lens or a concave mirror, and the eyepiece could be a lens or mirror.

The solution came from the spectacle makers. Historians of the subject have often had in mind a scenario somewhat like this: someone, a spectacle maker or his children, happens to combine a convex and a concave lens of the appropriate curvature and notices that the weather vane on a nearby church is magnified, and thus the telescope is invented by accident. But this is to suppose that the hundreds of spectacle makers in Europe were not familiar with combinations of spectacles, especially when the lens closest to the eye was concave. There is evidence that suggests that around the turn of the seventeenth century a number of men in Europe were familiar with such combinations of lenses, perhaps even in a tube, but that the enlarged image was fuzzy and blurred. The invention of the telescope was not some lucky accident; it was the result of gradual improvement of the optical quality of spectacle lenses. ${ }^{5}$

In 1634 the spectacle maker Johannes Sachariassen, son of Sacharias Janssen, one of the claimants for the honor of having invented the telescope, stated that his father had made the first spyglass in the Netherlands in 1604, after one in the possession of an Italian dated $1[5] 90 .{ }^{6}$ The device owned by the Italian was a tube with two lenses, and we may surmise that the image it produced was enlarged but fuzzy. At about the same time, the Italian poet,

\footnotetext{
${ }^{3}$ Eileen Reeves, Galileo's Glassworks:The Telescope and the Mirror. Harvard University Press, 2008. See also [3].

${ }^{4}$ William Bourne, A treatise on the properties and qualities of glasses for optical purposes, according to the making, polishing, and grinding of them, ca. 1580. See [4].

${ }^{5}$ See Willach, The Long Road, 93-97.

${ }^{6}$ Journal tenu par Isaac Beeckman de 1604 à 1634, avec une introduction et des notes par C. De Waard, (4 vols., The Hague: Martinus Nijhoff, 1939-1953), III: 376. See also Van Helden, Invention, p. 53.
} 
Fig. 2 Entry concerning Hans Lipperhey's patent application in the minutes of the meeting of the States General of the Netherlands, 2 October 1608. Courtesy Rijksarchief, The Hague

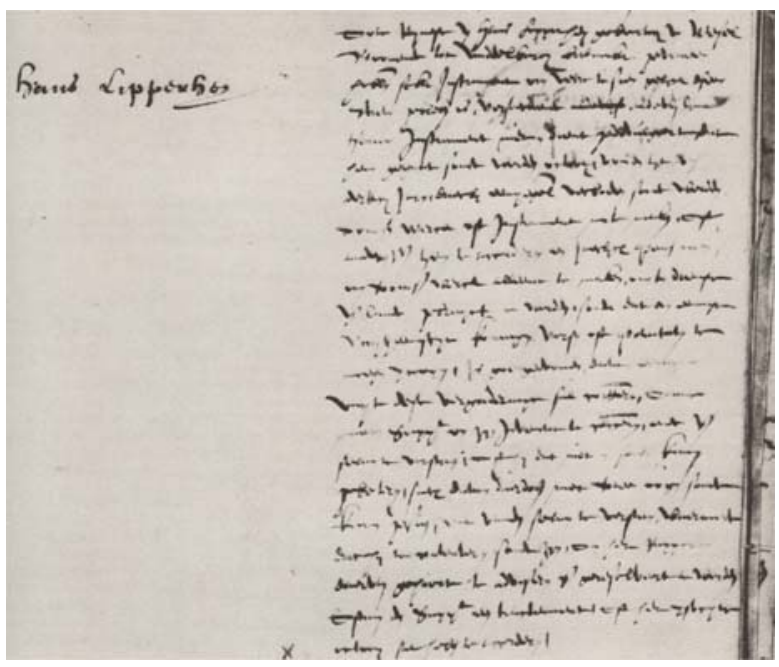

Raffaello Gualterotti, had a similar device but put it aside because it was "a feeble thing." In Italy and the Netherlands-and presumably in other regions of Europe as well-devices such as these were present, but they were feeble things. What was wrong with them?

Although lens-grinding and polishing techniques had improved greatly in the sixteenth century, the area of the best spectacle lenses that was figured accurately remained small-a circle of perhaps a centimeter in diameter centered on the optical axis. Since these lenses were used as spectacles, there was no specific drive to make that area larger. In Middelburg, capital of the province of Zeeland, one of the "United Provinces," Italian glass-making techniques were practiced. And it was here that a counter-intuitive move was made: the objective lens of one of those early devices was stopped down drastically, from about 3 to $1 \mathrm{~cm}$. The result was that the enlarged images seen through it were now reasonably clearly defined (Fig. 1). The spyglass was born, and the man who claimed it as his own was the spectacle maker Hans Lipperhey.

On 25 September 1608, Lipperhey set out from Middelburg with his spyglass and a letter of recommendation from the provincial government. Upon his arrival in The Hague, he presented his instrument to Prince Maurice of Nassau, commander-in-Chief of the Dutch armed forces. Maurice was impressed and sent the instrument to the States General, the national government, to decide whether to grant Lipperhey a patent (Fig. 2). Because the instrument could be easily copied, or even constructed after one heard a description of it, Lipperhey was not granted a patent; however, the gentlemen ordered two

\footnotetext{
${ }^{7}$ Raffaello Gualterotti to Galileo, 24 April 1610, Le Opere di Galileo Galilei, X: 341-342. Settle, "Danti, Gualterotti, Galileo;" and Van Helden, Invention, p. 45.
} 
more spyglasses, this time binocular and with lenses made of rock crystal. For these he was handsomely rewarded. ${ }^{8}$

\section{Galileo's telescope}

Within 2 weeks of Lipperhey's patent application, the States General received a petition from Jacob Metius of Alkmaar, who claimed to have the same instrument, although, he admitted, not as good as Lipperhey's; and from Middelburg came news that there was another person there who claimed to know the secret of making spyglasses. ${ }^{9}$ A newsletter printed in The Hague early in October was sent to the major European cities in diplomatic pouches, ${ }^{10}$ and a French soldier departed from The Hague for Paris with knowledge of how to make spyglasses. ${ }^{11}$ In November, the newsletter was received by Paolo Sarpi, who shared its content with Galileo. ${ }^{12}$ We can get some idea of what Galileo's first, three-powered spyglass looked like from a sketch made in August 1609 of the first actual spyglass to arrive in Naples, by the internationally known polymath, Giambaptista della Porta (Fig. 3).

Della Porta wrote that the larger tube was one (Neapolitan) palmo in length (ca. $26.5 \mathrm{~cm}$ ) and 3 in. (oncie, ca. $6.5 \mathrm{~cm}$ ) in diameter; the smaller tube was 4 in. long (ca. $9 \mathrm{~cm}$ ), and slightly smaller than the longer tube, so that it could slide into it. This instrument magnified three or our times. It is interesting to note that the objective aperture is very small, of the order of $1 \mathrm{~cm} .{ }^{13}$

Over the next 6 months, Galileo steadily improved his skills as a lens maker, and progressed to instruments that magnified 20 times with reasonable quality by December of that year. It was at this point that he began to make his discoveries: mountains on the Moon, the difference in the telescopic appearances of stars and planets, and the satellites of Jupiter. His little book, Sidereus Nuncius came off the press in March 1610. Galileo became an international celebrity, and he moved back to his native Tuscany, where he was appointed "Philosopher and Mathematician to the Grand Duke."

In the meantime, he continued his observations. In July 1610 he discovered that Saturn is flanked by two bodies that do not move with respect to each other or the planet, and by the end of that year he was able to verify that Venus goes through phases like the Moon, and this proved that it, and by implication Mercury as well, goes around the Sun [5].

\footnotetext{
${ }^{8}$ Van Helden, Invention, 35-38, 42-43.

${ }^{9}$ Van Helden, Invention, 38-40

${ }^{10}$ Anonymous, Ambassades du Roy de Siam envoyé à lÉxcellence du Prince Maurice, arrivé à la Haye le 10 septemb. 1608 (The Hague, October 1608). See Embassies of the King of Siam sent to his Excellency Prince Maurits, arrived in The Hague on 10 September 1608, ed. Huib Zuidervaart (Wassenaar, 2008); Van Helden, Invention, 40-42;

${ }^{11}$ Van Helden, Invention, 43

${ }^{12}$ Reeves, Galileo's Glassworks, 122-138

${ }^{13}$ Giambaptista della Porta to Federico Cesi, 28 August 1609, Galileo, Opere, X: 252
} 
Fig. 3 Drawing of a spyglass by Giambaptista della Porta, 28 August 1609. Le opere di Galileo Galilei. Edizione Nazionale, vol. 10 (1968), p. 252

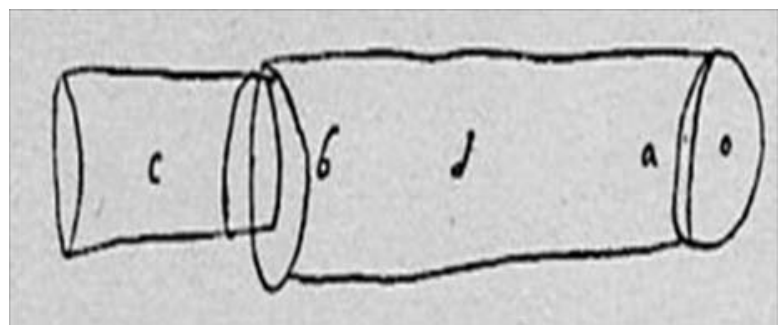

By that time, other observers were scrutinizing the heavens with telescopes of various powers and qualities. The study of sunspots was therefore initiated not by Galileo, although he had observed them earlier, but by Johannes Fabricius in Osteel, East Frisia, and by Christoph Scheiner. Galileo became involved in a controversy with Scheiner over the interpretation of the spots: Scheiner claimed that they were satellites of the Sun transiting the solar disc, while Galileo argued that they were like our clouds and on or near the surface of the Sun [6]. At stake was the perfection of the Sun and by extension the entire heavens. His arguments were convincing, even to Scheiner, and when Istoria e dimostrazioni intorno alle macchie solari e loro accidenti was published, in 1613, the arguments against the Ptolemaic-Aristotelian cosmology and supporting the system of Copernicus were so many that Galileo, although cautious in print, was defending the Copernican system openly in Florence. This was the point at which the Inquisition became involved. Three years later Copernicus's book, published in 1543, was put on the Index of Forbidden Books (until corrected), and Galileo was told not to hold or defend the heliocentric system. When he disobeyed this order, in 1632, the Inquisition condemned him to prison for life. He spent his remaining time under house arrest in his villa near Florence.

\section{From the "Galilean" to the "astronomical" telescope}

Galileo made his earth-shattering discoveries between 1609 and 1611. By the summer of 1611, the mathematicians of the Jesuit Collegio Romano had verified these discoveries. The phenomena were accepted as real; the attention now shifted to interpreting them. ${ }^{14}$ Except for some minor additions, such as Simon Marius's discovery of the Andromeda nebula (1612), no further discoveries were made. What remained were elaborations: working out the parameters of the orbits of Jupiter's moons in the hope of solving the problem of longitude at sea; mapping the Moon, perhaps with an eye toward using

\footnotetext{
${ }^{14}$ The mathematicians of the Collegio Romano to Robert Cardinal Bellarmine, 24 March 1611, Galileo, Opere, XI: 92-93.
} 
the method of lunar dichotomy (first described by Aristarchus of Samos in the third century BC) to determine longitude; and continuing observations of sunspots in order to determine the angle of the axis of rotation of the Sun. The telescope also made better observations of solar eclipses possible and opened the door to observing transits of Venus and Mercury.

But the instrument had its limitations. The small field of view, perhaps 15 arc min, limited magnification to about 20, and what modern astronomers call eye relief was very poor: the exit pupil was larger than the pupil of the eye, which meant a shifting field when the eye moved laterally to the optical axis. Because there was no fixed point for positioning the eye, the field was even affected by motion parallel to the optical axis.

Let us suppose that the apertures of Galileo's early telescopes were about $1.5 \mathrm{~cm}$, and that his dark adapted pupil was half that. This means that the telescope gathered four times as much light as his naked eye, enough to show the satellites of Jupiter, about sixth magnitude, but not enough to reach much deeper into the solar system and reveal other satellites or surface features on the planets. We can thus say that by 1611 the potential of the Galilean telescope for discovery had been exhausted. Further discoveries had to wait for a different type of telescope.

As argued above, the combination of a strong concave and a weak convex lens produced obvious magnification. Combining two convex lenses, one strong and the other weak, did not, however, produce an obvious effect. The eyepiece has to be positioned by exactly its focal distance beyond the focal point of the objective. The "astronomical telescope" therefore came not out of the background of spectacle making, as the Galilean telescope did, but rather out of more theoretical considerations. In his Dioptrice of 1611, Johannes Kepler wrote that replacing the concave eyepiece by a convex one would also produce the telescopic effect, although the image would be inverted. To reinvert it, yet another convex lens would be necessary. ${ }^{15}$

There was no obvious advantage to this configuration, and one clear disadvantage: it showed objects on earth inverted. This type of telescope was not immediately put into practice. One application where it would have an advantage was projecting an image through the telescope. The Galilean instrument produced an inverted projected image whereas the Keplerian version produced an erect image. It was Christoph Scheiner who, after learning the projection technique from Galileo, continued his investigations of sunspots and around 1615 first used a Keplerian version for projecting the Sun's image. In his magnum opus on sunspots, Rosa Ursina (1630), Scheiner related that if this configuration was used in direct observation it would produce a much brighter image and a much larger field of view. The fact that the image was inverted did not matter in astronomical observation [8].

${ }^{15}$ Johannes Kepler, Doptrice (1611). See [7]. 
In the 1630s Francesco Fontana, a telescope maker in Naples, was the first to make astronomical telescopes with magnifications double those of the Galilean version, and his results slowly became known all over Europe through correspondence channels (His observations were not published until 1646.) By the early 1640s a hybrid terrestrial/astronomical telescope was offered for sale by the optician Johannes Wiesel in Augsburg. His telescopes had a removable erector lens. In 1645, the Capuchin monk Antonius Maria Schyrlaeus de Rheita published Oculus Enoch et Eliae, in which he spoke of yet a fourth lens, the field lens. (Rheita also introduced the terms objective and ocular into the language of telescopic astronomy. $)^{16} \mathrm{~A}$ new chapter in telescopic astronomy now began.

\section{The long refractor and further discoveries}

The substitution of the convex for the concave eyepiece made the problems of spherical and especially chromatic aberration worse. Thus, curvature had to be minimized, and therefore higher magnifications meant longer telescopes. Certainly a length of $3 \mathrm{~m}$ was already modest, when, in 1655, Christiaan Huygens in The Hague made his first research telescope. Its length was $12 \mathrm{ft}$, its field of view was $30 \mathrm{arc}$ min, and its magnification was $50 .{ }^{17}$ Recent test have shown that the objective of this instrument, preserved in the Utrecht science museum, was not very good (Fig. 4). ${ }^{18}$ But Huygens turned his telescope to the heavens at an auspicious time, as we shall see.

As mentioned above, Galileo had observed Saturn's strange appearances for the first time in July 1610 . He claimed he saw a central globe flanked by two smaller globes; in 1611, the mathematicians at the Collegio Romans claimed they saw an oval shape. In his third sunspot letter, printed in 1613, Galileo reported that since there had been no change in the positions of Saturn's "companions," he had lost interest, but that when he happened to look at the planet again in 1612 he was surprised to see the appendages gone. Had Saturn devoured his children [11]?

Since Saturn's appearance was neutral in the debate between the world systems, the problem was only occasionally discussed until the 1640s, when a new generation of telescopic observers usually armed with better telescopes took on the problem. By about 1655 the different appearances had been catalogued and some astronomers were beginning to formulate theories to explain them. What they were not looking for was a satellite of the planet.

\footnotetext{
${ }^{16}$ Rolf Willach [9]. See also [10].

${ }^{17}$ Christiaan Huygens De Saturni luna observatio nova (1656), Oeuvres Complètes, XV: 177; see also, 10-11.

${ }^{18}$ Rolf Willach, private communication.
} 
Fig. 4 Ronchi interference test of the objective of the telescope with which Huygens discovered Saturn's largest moon in 1655 . The lens bears the inscription Admovere oculis distantia sidera nostris (from Ovid's Fasti), part of the anagram he used to hide his discovery of Saturn's moon, Oeuvres Complètes de Christiaan Huygens, vol. 15 (1967), p. 13

\section{Utrecht Museum Li38}

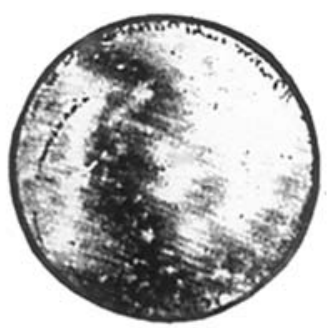

\section{Christian Huygens 1655}

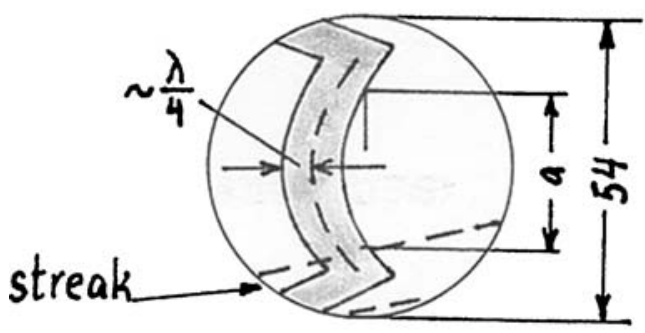

\section{allowed aperture for $\frac{\lambda}{4} \quad a=30 \mathrm{~mm}$ focal length $f=337 \mathrm{~cm}$}

The Saturnian moon we now call Titan, $M=8$, had been within the grasp of the best telescopes for about a decade, but its motion around the planet was a large ellipse (because its orbital plane more or less coincides with the ring plane). Observers such as Johannes Hevelius in Gdansk had seen it but considered it a fixed star. When the younger Huygens trained his telescope on the planet, early in 1655 , he quickly noticed a bright little star moving back and forth on a straight line through Saturn. A new chapter of discoveries had begun.

The clue that led Huygens to his ring-theory was the fact that as Saturn's appendages became smaller they kept their lengths (Fig. 5). In England,

Fig. 5 Christiaan Huygens's first recorded observations of Jupiter and Saturn. Oeuvres Complètes de Christiaan Huygens, vol. 15 (1967), p. 35

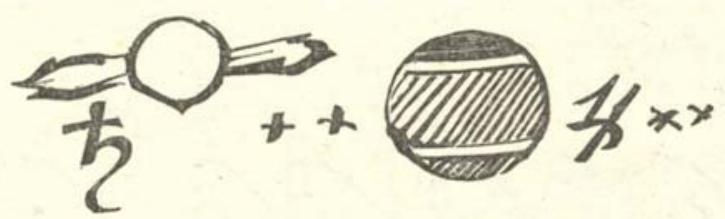


Christopher Wren had observed the same and arrived at the conclusion that a very thin elliptical "corona" was attached to the planet in two places and that it turned or librated about this axis to produce the observed appearances. Huygens's solution certainly wasn't a matter of seeing a ring: he solved the problem late in 1655 or early 1656, during and shortly following the planet's conjunction with the Sun, and when the planet appeared its appendages were entirely gone. Rather, Huygens started from the supposition that Saturn was the center of its own (Cartesian) vortex. Since the newly discovered moon had a period of about 16 days and the planet was thought to rotate around its axis in a period not very different from the Earth on its axis, all matter in between had to revolve around the planet with periods less than 16 days. Presumably, the appendages or anses rotated around Saturn's axis in about a day, but their appearances changed much more slowly. A thin flat ring turning about the planet, and touching it nowhere was the solution: Annulo cingitur plane, tenui, ad eclipticam inclinato [12].

Huygens published a complete account of Saturn's moon and his ring solution in Systema Saturnium, 1659 (Fig. 6). This book was, however, more than a mere report about Saturn. Huygens also discussed his way of measuring angular distances in the field of view of his telescope by inserting thin rods into the focal plane of his telescope, and this led to the development of the screw micrometer in France, and the revival of William Gascoigne's micrometer in England. Having measured the angular diameters of the planets, Huygens made an educated guess of the Earth's apparent diameter as seen from the Sun, putting it halfway between those of Venus and Mars. His result was a solar parallax of 8.2 arc sec. Systema Saturnium thus also contained a measure of the solar system and everything in it [13].

Famous as he was because of his telescopic discoveries, Huygens's objectives were not as good as those made in Rome by Eustachio Divini and the new

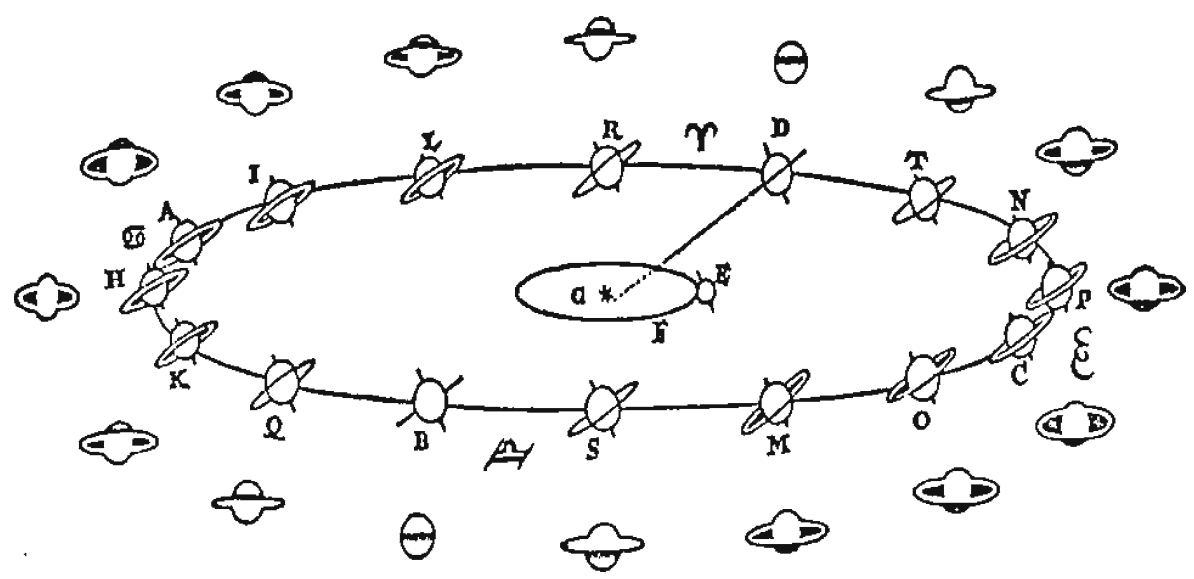

Fig. 6 Diagram demonstrating how a ring around Saturn can produce the various appearances. Oeuvres Complètes de Christiaan Huygens, vol. 15 (1967), p. 317 
telescope maker, Giuseppe Campani. And whereas Huygens's instruments had clear apertures of a few inches, by 1665 Campani was producing biconvex objectives with a clear aperture of $10 \mathrm{~cm}$ for a focal distance of $10 \mathrm{~m}$, with a peak-to-valley departure from the spherical of 0.14 wavelengths. Against these lenses, no one could compete [14].

No wonder that virtually all discoveries after that of Titan were made with Campani telescopes, especially by Giovanni Domenico Cassini, professor of mathematics at the University of Bologna and advisor to the Pope on engineering matters, and beginning in 1669 a member of the new Académie Royale des Sciences in Paris and head of the new royal observatory there. Cassini observed and published surface markings on Mars (earlier seen by Huygens but not published), determined the rotation periods of Mars and

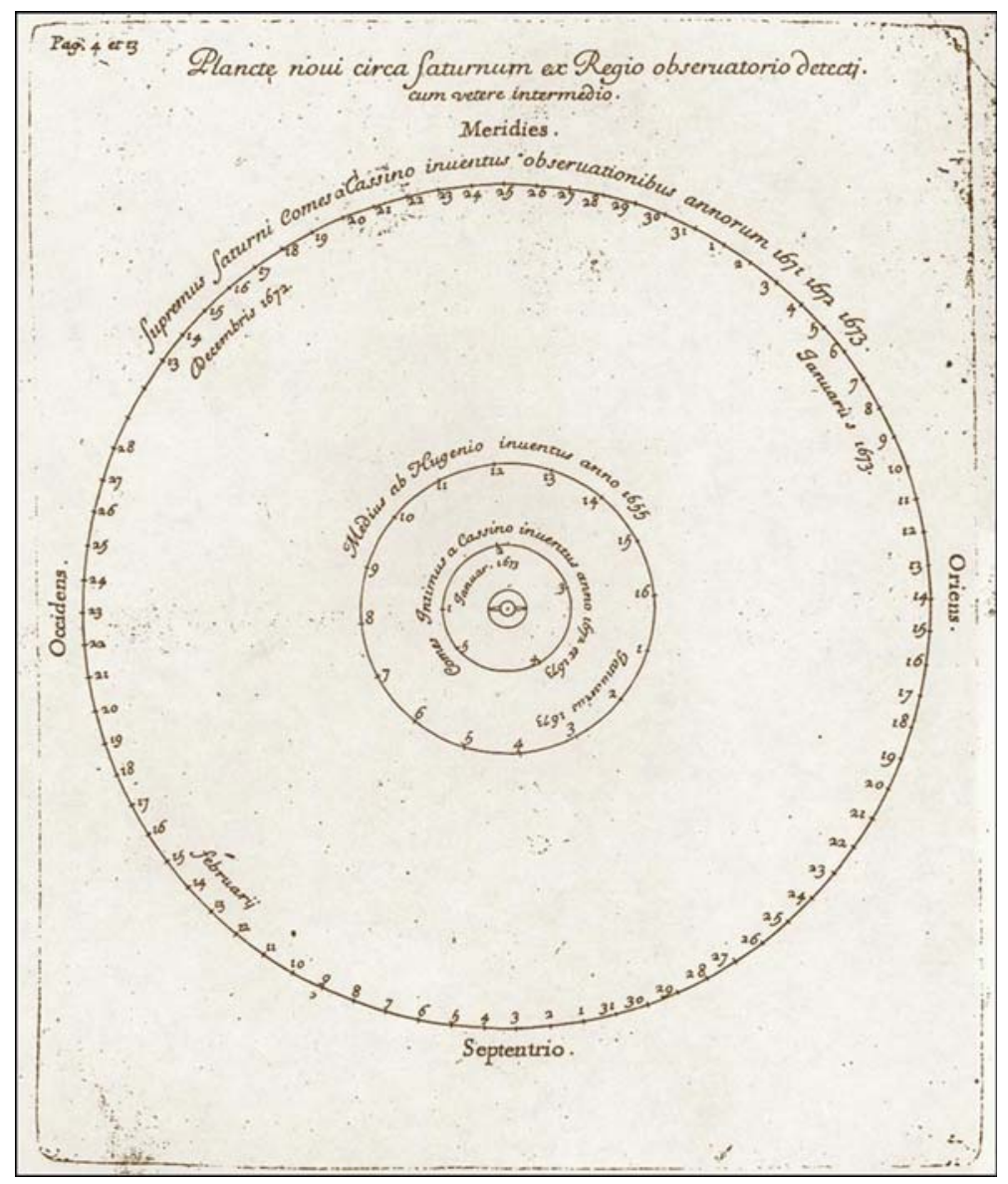

Fig. 7 Illustration from Giovanni Domenico Cassini, Decouverte de deux nouvelles planetes autour de Saturne. Paris 1673 


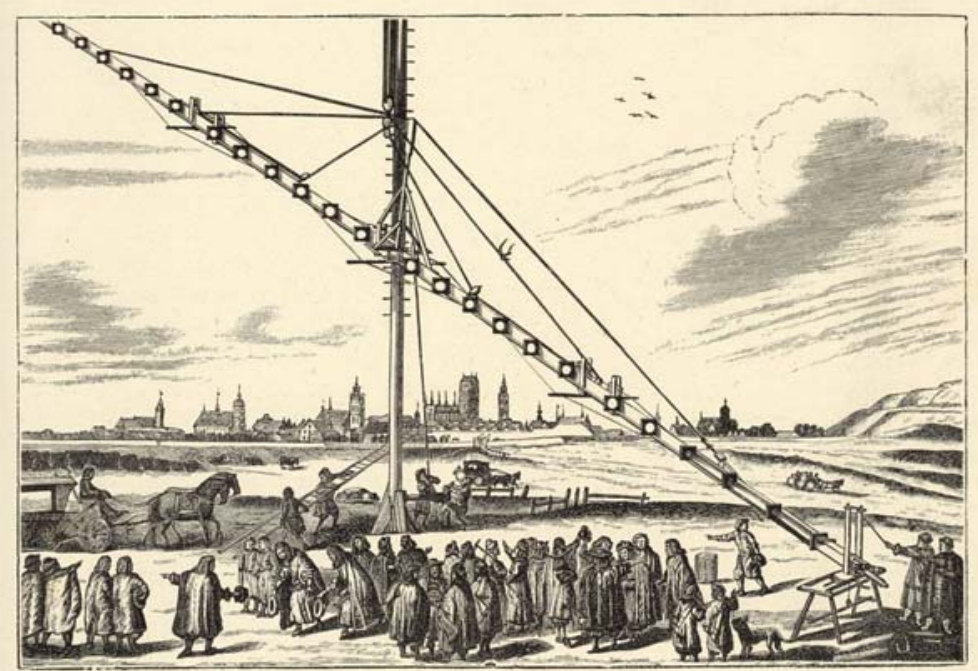

Fig. 8 40-45 m telescope erected on the beach near Gdansk by Johannes Hevelius. Machinae Caelestis pars prior. Gansk, 1673

Jupiter, and discovered no fewer than four satellites of Saturn, Iapetus and Rhea in 1671 (Fig. 7) and 1672, ${ }^{19}$ and Tethys and Dione (1684) [12].

Campani's telescopes were of fairly modest lengths compared to those of some of his contemporaries. In the race to make telescopes more and more powerful, telescopes as long as 45 meters were already being raised around 1670 (Fig. 8). These were high-prestige items, useless for astronomical observation. With long telescopes, the only sensible thing to do was to do away with the tube. It appears that observers had been doing that since the 1660s. In 1684, Huygens published a little tract in which he proposed a design for an aerial telescope in which the housing holding the objective was mounted on a ball joint so that by means of a string the eyepiece could be aligned with the objective (Fig. 9) [15]. His own telescopes could not match those of Campani for clarity, and Huygens was never able to see for himself the last two satellites of Saturn discovered by Cassini.

As the seventeenth century drew to a close, the long refractors gradually fell out of favor because of diminishing returns for increasing unwieldiness. In the first quarter of the eighteenth century they were used a few times, and after that they disappeared from astronomy, to be replaced by the reflecting telescope. By this time, there was a new cosmology, Newton's infinite space ruled by the law of universal gravitation, and the astronomers' new solar system which illustrated universal gravitation by the satellites of Jupiter and Saturn and gave the system roughly its modern dimensions (Fig. 10).

\footnotetext{
${ }^{19}$ Giovanni Domenico Cassini, Decouverte de deux nouvelles planetes autour de Saturne. Paris 1673.
} 
Fig. 9 Christiaan Huygens's design of a telescope without tube. Astroscopia compendiarium. The Hague, 1684

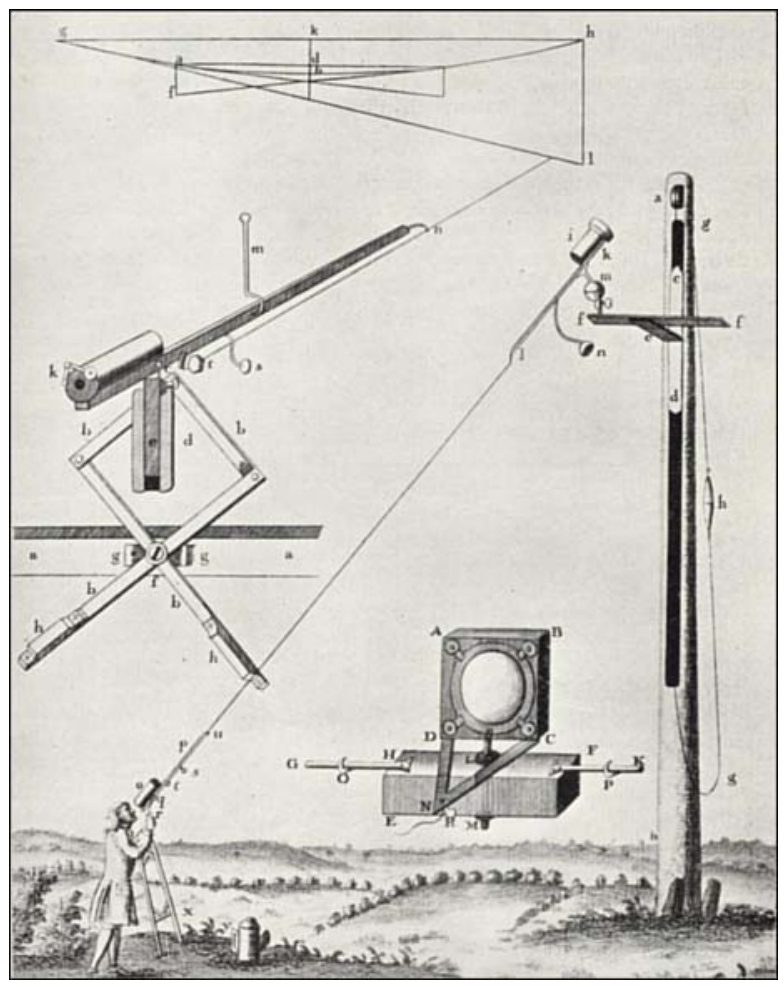

Fig. 10 Sizes of the planets compared with the Sun's. Christiaan Huygens, Cosmotheoros, The Hague 1698, p. 123

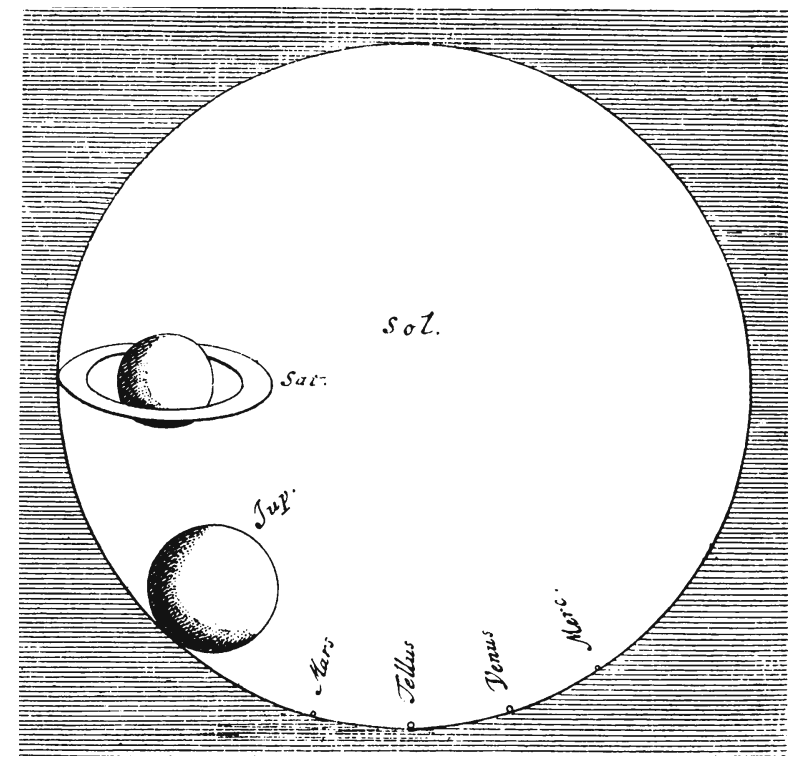


Open Access This article is distributed under the terms of the Creative Commons Attribution Noncommercial License which permits any noncommercial use, distribution, and reproduction in any medium, provided the original author(s) and source are credited.

\section{References}

1. Settle, T.B.: Danti, Gualterotti, Galileo: their telescopes? Atti. Fond. Giorgio Ronchi 61(5), 625-638 (2006)

2. Pelling, N.: Who invented the telescope? Hist. Today 58(10), 26-31 (2008)

3. Dupré, S.: Ausonio's mirrors and Galileo's lenses: the telescope and sixteenth-century practical optical knowledge. Galilæana 2, 145-180 (2005)

4. Van Helden, A.: The invention of the telescope. Trans. Am. Phil. Soc. 67, 30-34 (1977)

5. Van Helden, A.: Sidereus Nuncius or the Sidereal Messenger, pp. 102-109. University of Chicago Press, Chicago (1989)

6. Reeves, E., Van Helden, A.: Galileo and Scheiner on Sunspots, 1611-1613. University of Chicago Press, Chicago (2009, in press)

7. Riekher, R. (ed.): Johannes Kepler Schriften zur Optik, 1604-1611, Ostwald Klassiker der Exakten Wissenschaften, vol. 198, pp 485-492. Verlag Harri Deutsch, Frankfurt a. M. (2008)

8. Van Helden, A.: The 'astronomical telescope,'1611-1650. Ann. Ist. Mus. Stor. Sci. Fir. 1, 13-36 (1976)

9. Willach, R.: Schyrl de Rheita und die Verbesserung des Linsenfernrohres in der Mitte des 17. Jahrhunderts. Sterne Weltraum 1, 102-110, 186-192 (1995)

10. Thewes, A.: Oculus Enoch... Ein Beitrag zur Entdeckungsgeschichte des Fernrohrs, pp. 13-15. Verlag Isensee, Oldenburg (1983)

11. Van Helden, A.: Saturn and his anses. J. Hist. Astron. 5, 105-121 (1974)

12. Van Helden, A.: Annulo Cingitur: the solution of the problem of Saturn. J. Hist. Astron. 5, 155-174 (1974)

13. Huygens, C.: Systema Saturnium. Oeuvres Complètes XV, 343-351 (1659)

14. Miniati, M., Van Helden, A., Greco, V., Molesini, G.: Seventeenth century telescope optics of Torricelli, Divini, and Campani. Appl. Opt. 4, 644-647 (2002)

15. Huygens, C.: Astroscopia compendiarium. Oeuvres Complètes XV, 201-231 (1684) 